\title{
URBAN GROWTH SIMULATION USING SLEUTH IN AFYONKARAHISAR (TURKEY)
}

\author{
Mustafa Mutlu Uysal, Murat Uysal
}

Original scientific pape In this study, the change in city growth of Afyonkarahisar in the adjacent area in the future was estimated using the SLEUTH model. The main objective of this study is to show the simulation of the change in the urban growth of Afyonkarahisar until 2030 with the SLEUTH model, a cellular automata model. For this purpose, two different growth scenarios have been developed. As a result of the study, with the current growth scenario, urban development from 2011 to 2030 will increase by 3115 hectares, and it is seen that 2300 hectares of pasture areas will be destroyed with this increase. It is found that 2000 ha of natural areas can be protected from urbanization and the wrong land use of the city's natural resources having social and economic importance can be avoided with the controlled growth scenario.

Keywords: remote sensing; simulation; SLEUT; urban modelling

Simulacija razvoja grada primjenom SLEUTH modela u Afyonkarahisar (Turska)

Original scientific paper

U ovoj se analizi procjenjuje promjena u razvoju područja oko grada Afyonkarahisar u budućnosti, primjenom SLEUTH modela. Osnovni je cilj prikazati simulaciju promjene razvoja grada do 2030 pomoću SLEUTH modela. U tu su svrhu razvijena dva različita modela razvoja. Kao rezultat analize ustanovljeno je da će uz postojeći scenarij razvoja, od 2011 do 2030 grad porasti za 3115 hektara, a to će rezultirati uništenjem 2300 hektara pašnjaka. Ustanovljeno je da se 2000 ha prirodnih bogatstava može zaštiti od urbanizacije i izbjeći kriva uporaba tog područja od ekonomske i društvene važnosti uz scenarij kontroliranog rasta.

Ključne riječi: prosuđivanje na daljinu; simulacija; SLEUT; urbano modeliranje

\section{Introduction}

The rapid increase in world population, the misuse of natural resources and the potential land use conflicts are the problems on the agenda of many developed and developing countries. In the past two centuries, despite only 6-fold increase in world population, the city's population has increased more than 100 times [1].

A city as a complex system is both static and dynamic as it is in a continuous change and development [2]. Irregular expansion of the cities has usually led to the extinction of available productive agricultural or forest areas. Sometimes changes in land use are made mandatory in order to provide the basic functions, such as shelter for people, food, transportation and recreation in a healthy manner. The entire city information must be mastered by all of the local authorities in order to overcome this problem in a healthy way [3].

In Geographic Information Systems (GIS), dynamic modelling as a tool of urban simulation has quickly gained popularity among city planners and managers in recent years. Cellular robot (cellular automata)-based urban growth model is perhaps the most impressive dynamic model in terms of technological development depending on the urban application.

In this study, the change in city growth of Afyonkarahisar in the adjacent area in the future (by the year 2030) was estimated using SLEUTH model. Assessment of the environmental impacts of urban growth and understanding the dynamics of complex urban systems require advanced methods and techniques like modelling and simulation. Several analytical and static models of urban growth such as the city geometry, developmental relationship between cities and economic functions have been developed based on various theories so far. However, these models simply describe urban growth and associated patterns rather than predicting future urban growth. A dynamic modelling approach should be preferred in order to understand the results of spatial urban growth $[4,5,6]$.

\section{Study area}

Afyonkarahisar is a city located in the Aegean region of Turkey. It is a very busy route as Afyonkarahisar location and it is centre of the transition from Central Anatolia and Eastern parts of the Anatolia to Aegean region. Due to high intensity of hot springs in the region of the city, there is also thermal spring's tourism. The surface area is $1029 \mathrm{~km}^{2}$ and the population 186991, the annual average temperature is $11,2{ }^{\circ} \mathrm{C}$, the average rainfall $43,9 \mathrm{~kg} / \mathrm{m}^{2}$ and altitude $1013 \mathrm{~m}$. The study area obtained from Afyonkarahisar Municipality, defines the adjacent area of about 30000 hectares (Fig. 1). The altitude is between $943 \div 1445 \mathrm{~m}$ and $80 \%$ of the area is within incline range of $0 \div 25 \%$ of the study area.

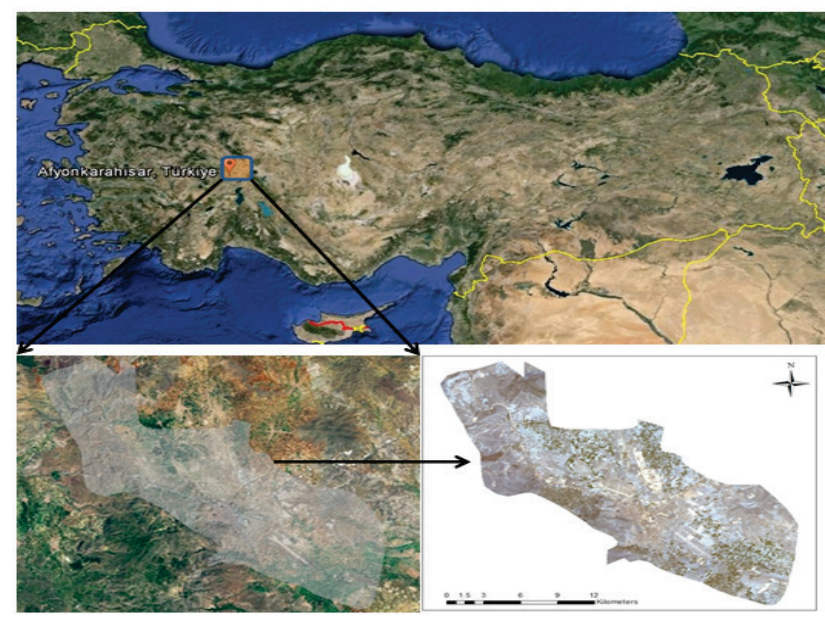

Figure 1 Afyonkarahisar location map (study area) 
Afyonkarahisar population is increasing rapidly due to the development of agriculture, stockbreeding, marble industry, thermal tourism, natural increase of population and the immigration from villages to cities (Fig. 2).

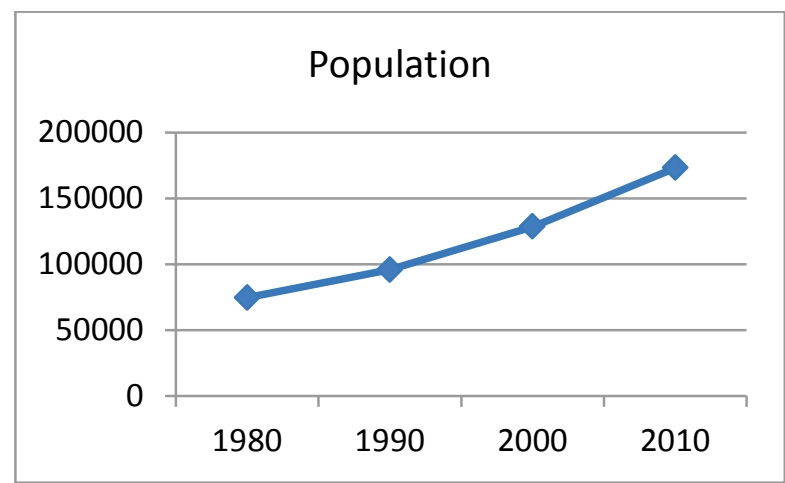

Figure 2 Afyonkarahisar population increase [7]

\section{Data used}

3.1 Satellite images (urban-Land use/Land cover)

4 Landsat Satellite Images were used in this study:

- 10.08.1987 dated Landsat 5 TM satellite images (Path/Row: 178/33)

- 19.08.1999 dated Landsat 7 ETM satellite images (Path/Row: 178/33)

- 06.08.2003 dated Landsat 5 TM satellite images (Path/Row: 178/33)

- 28.08.2011 dated Landsat 5 TM satellite images (Path/Row: 178/33)

Foururban layers $(1987,1999,2003,2011)$ and 2 land use / land cover layers $(1987,2011)$ were obtained from these images to use in Sleuth modelling.

\subsection{Digital elevation model (DEM)}

Aster satellites DEM (NW 38.30) data including the field of Afyonkarahisar Province is used in this study. The slope and shading (hill shade) maps were created from DEM data. Slope (percentage) layer has been used to prevent the urbanization of the areas above the maximum percentage pitch values. In this study, $25 \%$ were taken as the maximum slope value. The shading layer was only used to display the model results.

\subsection{Transportation data (Transportation)}

- $\quad 1987$ dated data showing major/important roads

- 1999 dated data showing major/important roads

2003 dated data showing major/important roads

- 2011 dated data showing major/important roads.

These road maps from 1987, 1999, 2003, and 2011 are created by digitizing Landsat TM satellite images.

\subsection{Excluded area map (Excluded layer)}

The excluded layer shows the region whose urban growth is undesired:

- On this map, regions such as parks, urban forests, and cemeteries excluded from growth are indicated considering the natural areas in the city of Afyonkarahisar. To what extent the excluded regions would be protected from growth was indicated by giving the numeric value $(0 \div 100)$. For example, while a value of 100 indicates that the area should definitely be excluded from urban growth $(100 \%$ protection), 50 shows that $50 \%$ of that area should be protected [8].

\section{SLEUTH implementations}

Landsat satellite images of the past years (1987, 1999, 2003, 2011) belonging to adjacent areas of Afyonkarahisar designated as the study area in this project were classified in a supervised manner and urban growth has been identified from the past to the present. Scenarios are simulated for the future in line with the growth determined as the second stage. The pixel-based urban growth model, SLEUTH, has been used for the predictions.

\subsection{Input data for SLEUTH}

All data layers must be grayscale in 8-bits GIF format in order for Sleuth model to work [8]. Therefore, after all data layers had the same projection (UTM 37N), the same resolution $(30 \mathrm{~m})$, and the same size $(937 \times 865)$, they were converted to grayscale GIF format with the help of ArcGIS. To make an estimate of the future city growth and land use / land cover change with the Sleuth model;

- 2 land use / land cover layers,

- 4 urban fabric layers,

- At least 2 road layers,

- Excluded area,

- Percentage slope and

- $\quad$ Shading layers are required.

In this study, 2 land use / land cover layers (1987 and 2011), and 4 urban fabric layers (1987, 1999, 2003, 2011), 4 path layers (1987, 1999, 2003, 2011), 2 excluded areas and 1 percentage slope, and shading layers are used (Tab 1).

Table 1 Used Data Layers

\begin{tabular}{|l|c|c|c|}
\hline \multicolumn{1}{|c|}{ Layer Name } & $\begin{array}{c}\text { Layer } \\
\text { Number }\end{array}$ & Year & Source \\
\hline Slope & 1 & & DEM \\
\hline LU/LC & 2 & 1987,2011 & Landsat \\
\hline Exluded Layer & 2 & & Landsat \\
\hline Urban & 4 & $\begin{array}{c}1987,1999, \\
2003,2011\end{array}$ & Landsat \\
\hline Transportation & 4 & $\begin{array}{c}1987,1999, \\
2003,2011\end{array}$ & Digitization \\
\hline Hill Shade & 1 & & DEM \\
\hline
\end{tabular}

Before classification, thermal band (band 6) was removed from all satellite images. Bands 1, 2, 3, 4, 5, and 7 were included in the classification.

The study area was cut one by one from Landsat images using an adjacent area border. Images for the years 1987 and 2011 were classified both as unsupervised and supervised in ERDAS Imagine program and supervised classification data were preferred in the study and the study area was divided into 5 classes (Fig. 3 and 
Fig. 4): Urban, Agriculture, Forestry, Rangeland and other.

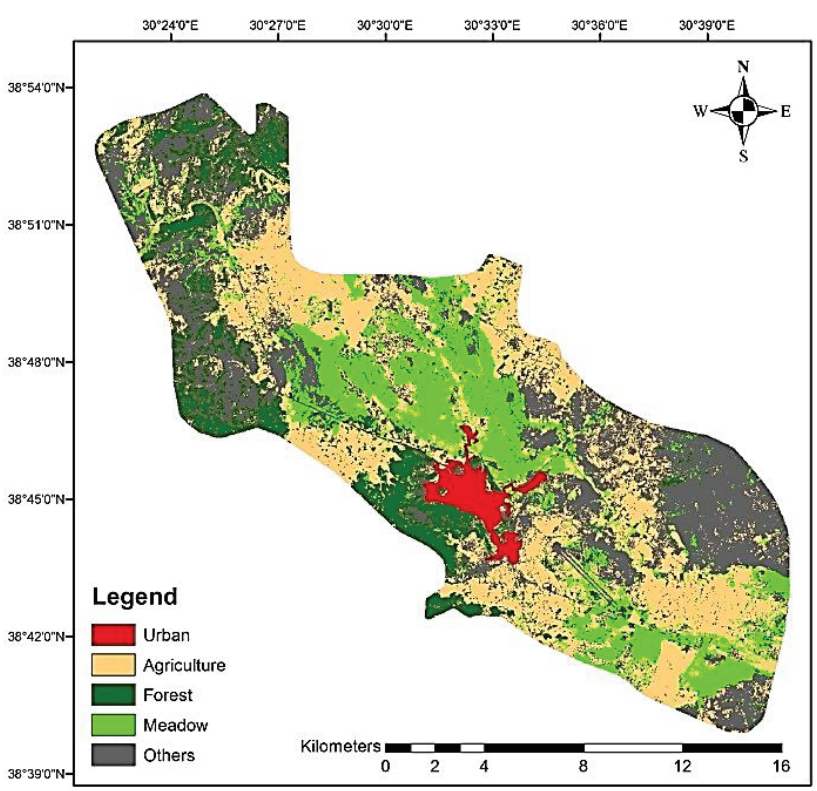

Figurre 3 Afyonkarahisar 1987 dated Land Use / Land Cover Layer (Supervised classification)

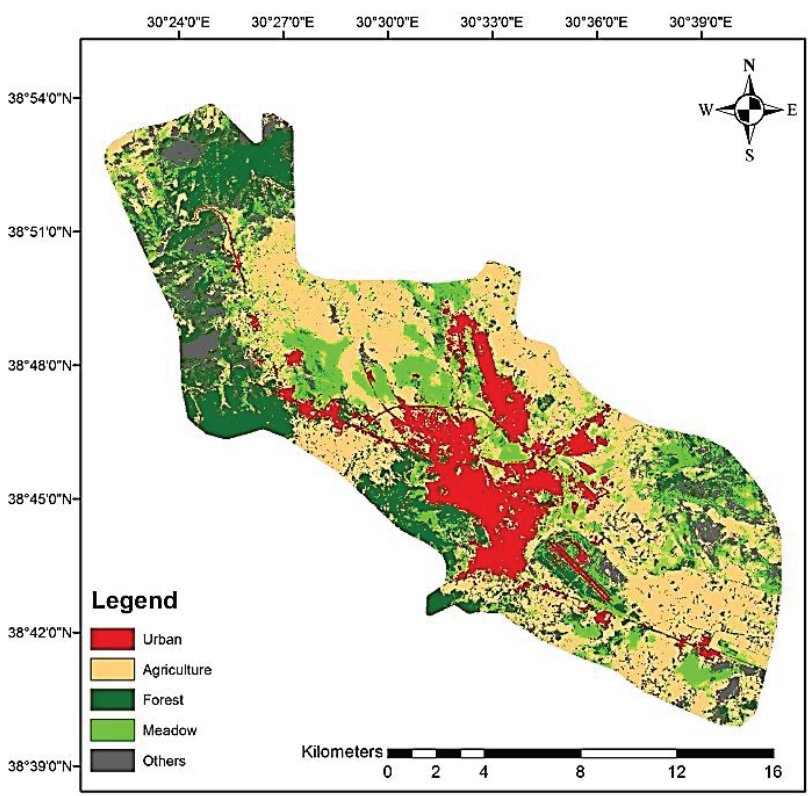

Figure 4 Afyonkarahisar 2011 dated Land Use / Land Cover Layer (Supervised classification)

Table 2 Afyonkarahisar 1987 dated LU/LC accuracy analysis

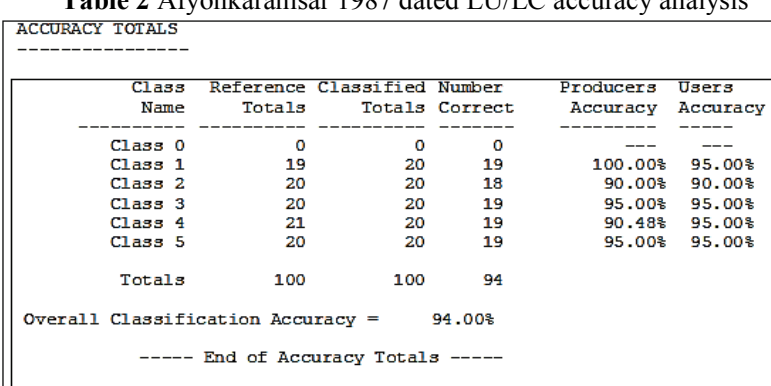

KAPPA $\left(K^{\wedge}\right)$ STATISTICS

-
Images for the years 1987 and 2011 were classified by the method of supervised classification and land use / land cover layers were produced. The error matrix is accepted as the most widely used method for determining the accuracy of classification [9, 10,11]. As a result of this accuracy analysis, the producers, the users, the overall classification, and kappa accuracies were calculated for 1987 and 2011 land use / land cover layers (Tabs. 2 and 3).

Table 3 Afyonkarahisar 2011 dated LU/LC accuracy analysis

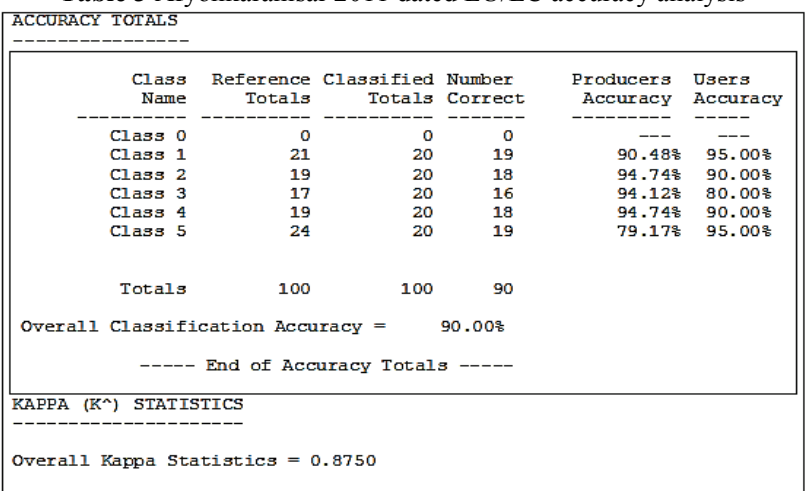

The only urban fabric was obtained from supervised classification results by using the images from 1999 and 2003 in the same manner with the help of ERDAS software. The urban fabrics for all years (1987, 1999, 2003, and 2011) are shown in Fig. 5. The urban growth for all years $(1987,1999,2003$,and 2011) is shown in Fig. 6.

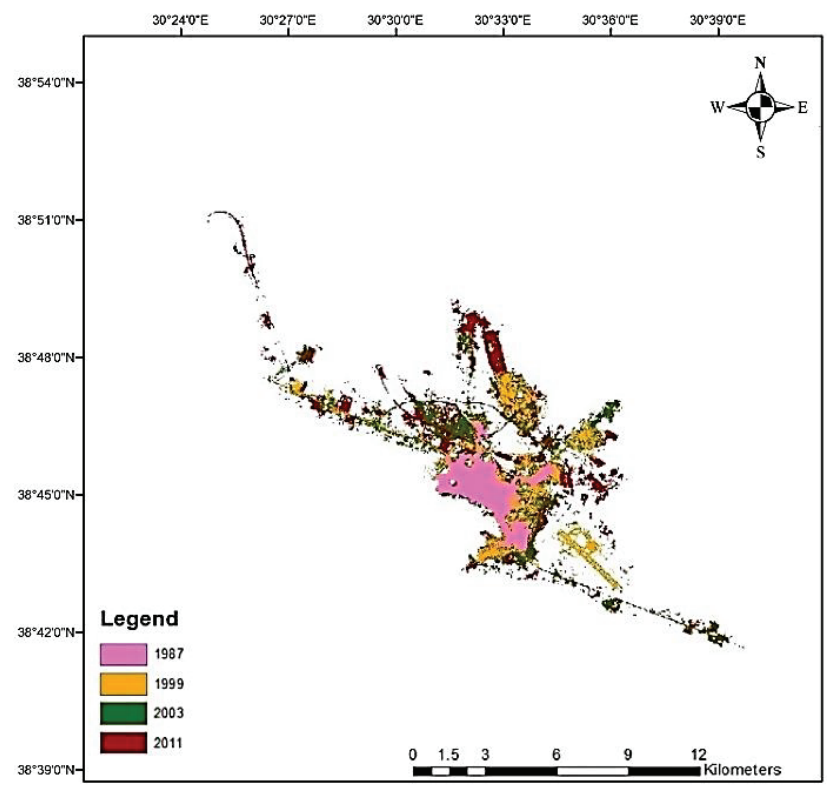

Figure 5 Afyonkarahisar Urban Layers

Roads from 1987, 1999, 2003, and 2011 dated satellite images were digitized with the help of ESRI ArcGIS and four different layers were produced in that way. Percentage slope and shading maps were created using the digital elevation model (Fig. 9 and Fig. 10 and altitudes in Fig 8). 


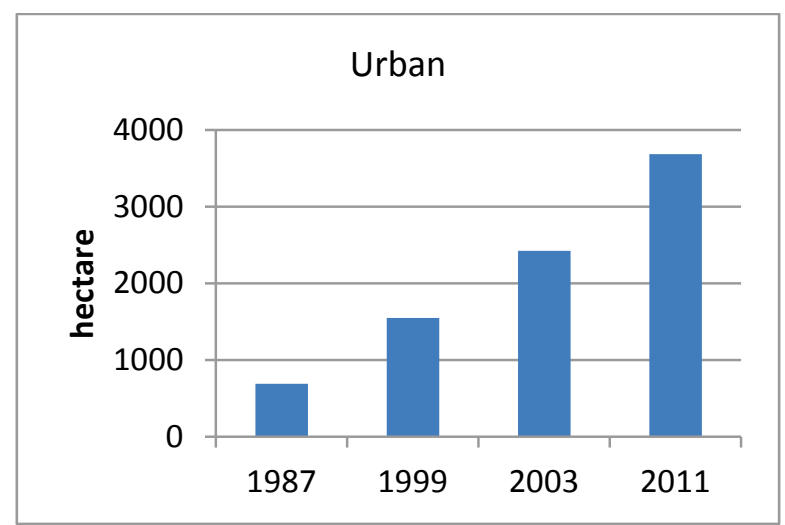

Figure 6 Afyonkarahisar Urban Growth $(1987 \div 2011)$

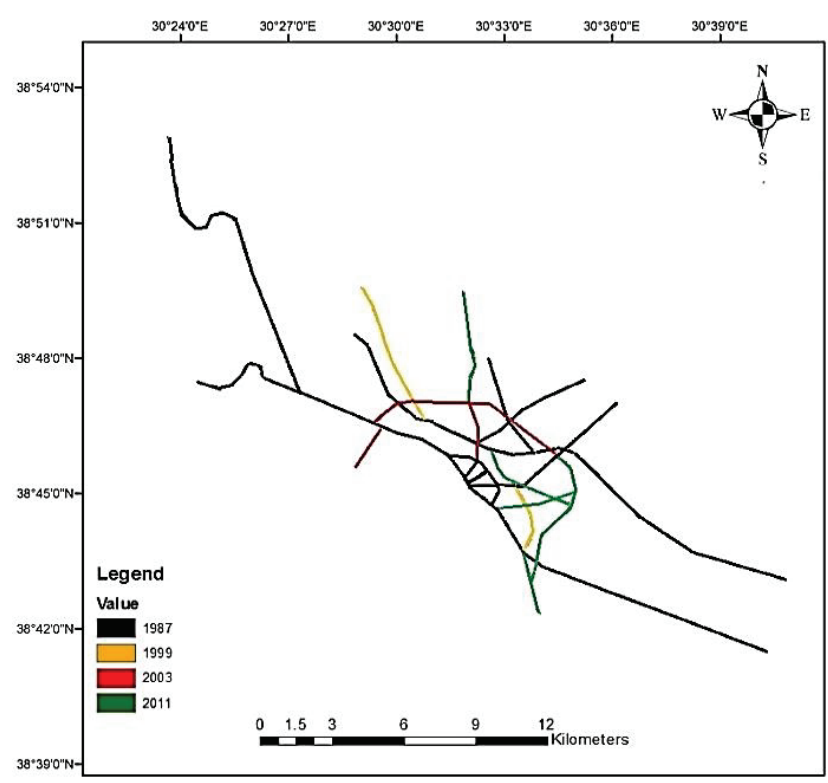

Figure 7 Afyonkarahisar Road Layers

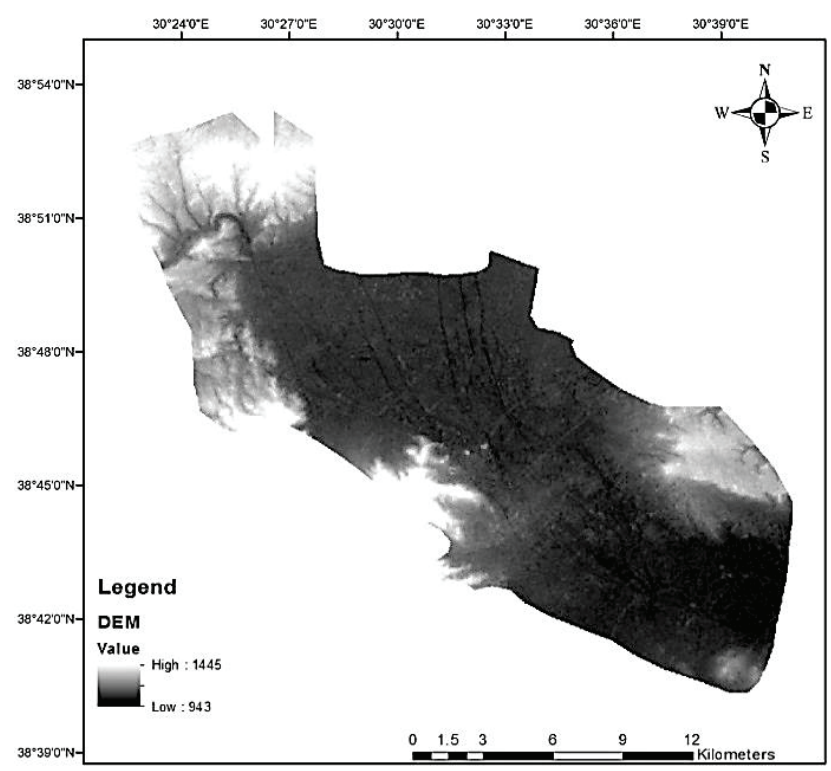

Figure 8 DEM (Digital Elevation Model).

Two excluded area layers which allow modelling the future urban growth change have been developed:

1) Excluded area of current growth (Fig. 11)

2) Excluded area of controlled growth (Fig. 12).

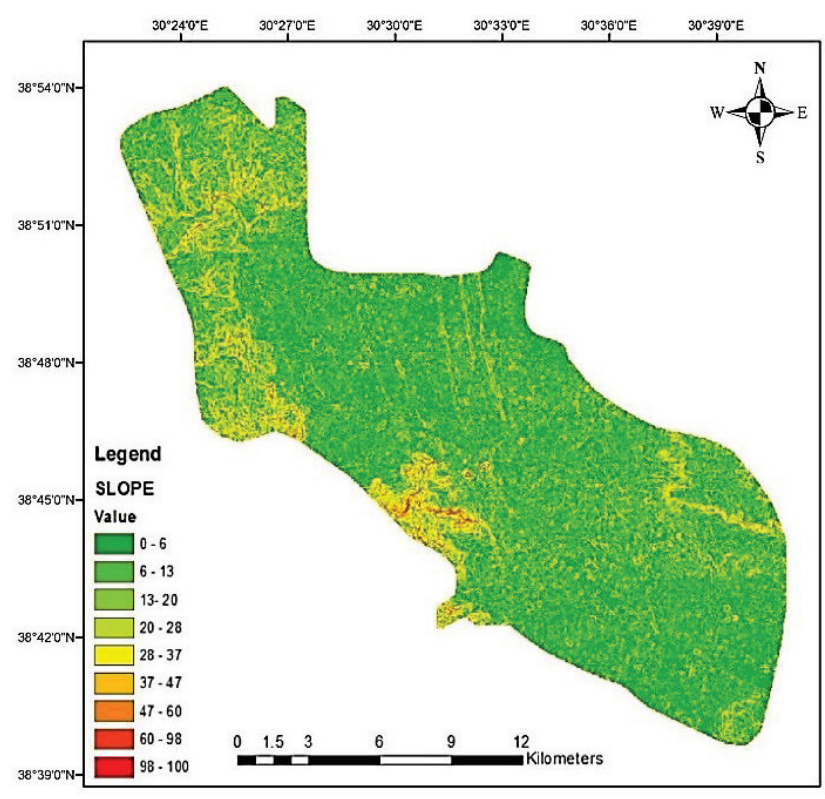

Figure 9 Afyonkarahisar Slope Layer

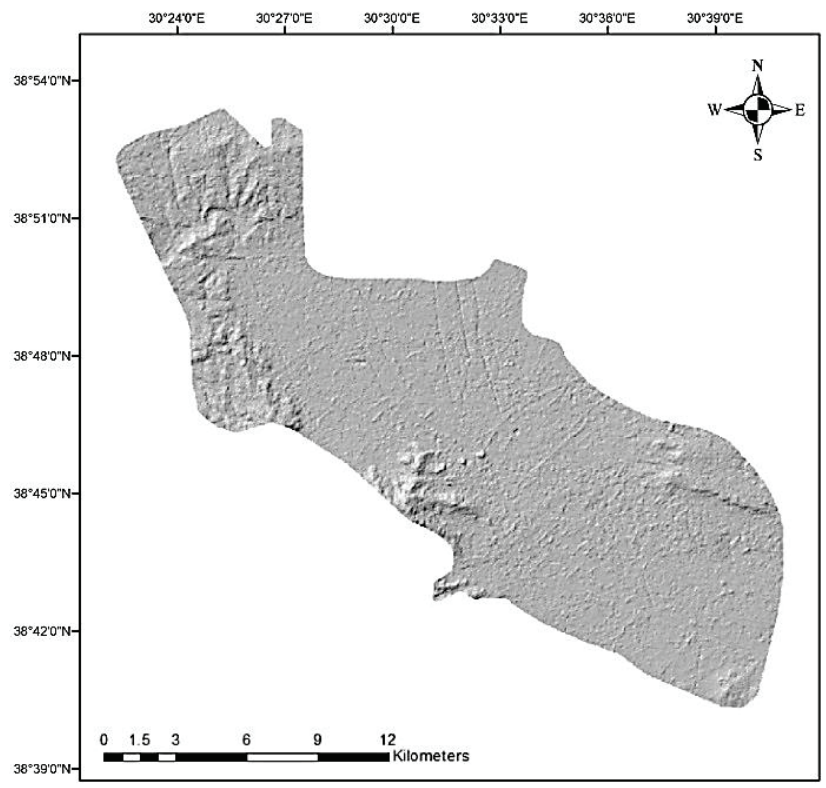

Figure 10 Afyonkarahisar Shading Layer

Each excluded area contains values from $0 \div 100$. For example, forest and park areas are given a value of 100 and it shows that the urban growth in this region is $100 \%$ restricted in the future. Natural or semi-natural habitats such as agricultural and green areas meadows have different values for each scenario. For example, low values for Scenario 1 (Current Growth) and high values for Scenario 2 (Controlled Growth) are given. The values of the excluded area layers developed under two different scenarios in this study are shown in Tab. 4.

Table 4 The Values of Excludes Area Layers

\begin{tabular}{|c|c|c|}
\hline LC/LU Classes & Current Growth & Controlled Growth \\
\hline Urban & 0 & 0 \\
\hline Agriculture & 40 & 80 \\
\hline Forest & 100 & 100 \\
\hline Meadow & 40 & 80 \\
\hline Others & 40 & 80 \\
\hline
\end{tabular}




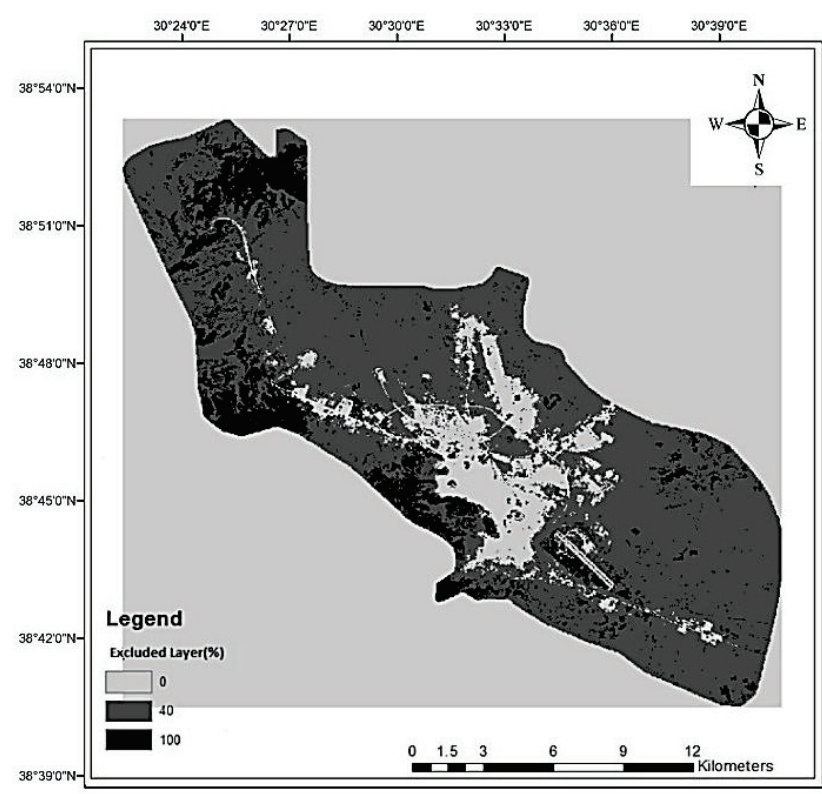

Figure 11 Excluded area of current growth

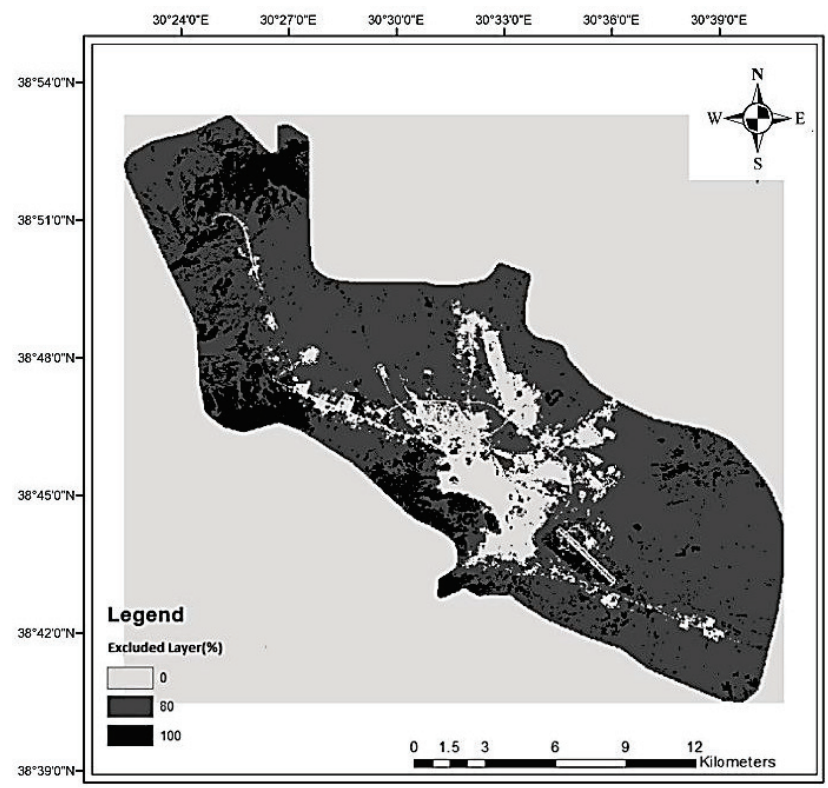

Figure 12 Excluded area of controlled growth

\subsection{Model calibration}

After the required data layers were created in GIF format to run the model, Sleuth model has been tested with the test data layers available within the model. Then Afyonkarahisar adjacent area has been run in test mode and it was found that the model worked perfectly.

The calibration phase is one of the longest phases to process by the computer. Out of these phases, final calibration has the longest computer processing time. The reason is that the final calibration processes in exact resolution $(30 \mathrm{~m})$. The quarter resolution $(120 \mathrm{~m})$ data are processed in coarse calibration. Afyonkarahisar adjacent area data took about 1 day to complete the coarse calibration phase; the fine calibration took 2 days, and final calibration phase was approximately 4 days. Of course, the time can vary according to the size of data, the speed of the computer (CPU), and the memory (RAM). This study was conducted on a desktop personal computer with $3 \mathrm{~GB}$ memory and 2,5 GHz speed.
After this 3-step calibration had finished, Derive Forecasting Coefficients phase was done, where the aim is to calculate the values used in prediction step which will be used in the calculation of future changes step. The values from this stage were used in prediction step. Parameter values which were obtained to be used in prediction step are shown in Fig. 13.

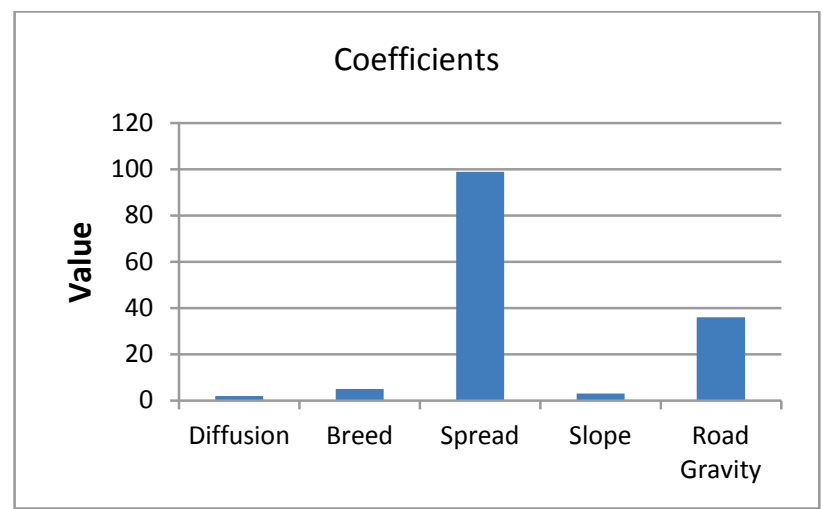

Figure 13 Parameter values to be used in prediction step

Accordingly, the spread parameters are likely to be the most effective in this modelling.

Then the efficiency of road gravity, breed, slope and diffusion parameters is seen respectively. While the slope efficiency was less as there was the mountainous area only in the southwest of the study area, it was seen that there was too much sprawl since it was plain and $0 \div 25$ $\%$ slope range in other aspects of the city, and significance of the road was effective in that, too.

\section{Results}

The effect of urbanization on natural or semi-natural habitats such as forests, agricultural lands and green space / meadows and the extent of urbanization were observed. By increasing $40 \%$ protection in the first scenario to 80 $\%$ protection in the second scenario, it was taken under high protection. Two different growth scenarios were created and prediction results were shown in Figs. 14 and 15 .

It is seen that the city showed less dispersed growth with the current controlled scenario and it was mostly within the city fabric boundary. The current growth leads to the excessive land consumption and the extinction of natural / semi-natural areas indirectly.

Due to $80 \%$ protection for natural and semi-natural areas, too much growth of the urban fabric has been blocked on controlled growth scenario (Figs. 15 and 16).

Future growth in Afyonkarahisar city showed a distribution in all directions except the southwest. The hilly area in the southwest extension restricted the city's development in this direction. If there is no restriction on urban growth, it is expected that there will be the extinction of meadows and this leads to the urbanization of fertile farmland. Until the year 2030, it is seen that the most damaged areas will be the meadows.

As shown in Fig. 14, the area covered by the city was founded on about 7000 hectares, based on the current growth scenario for Afyonkarahisar by 2030. Through a planned and controlled growth, the urban area will be about 5000 hectares in 2030, which means approximately 
2000 hectares will be saved. This field consists of meadows and the others.

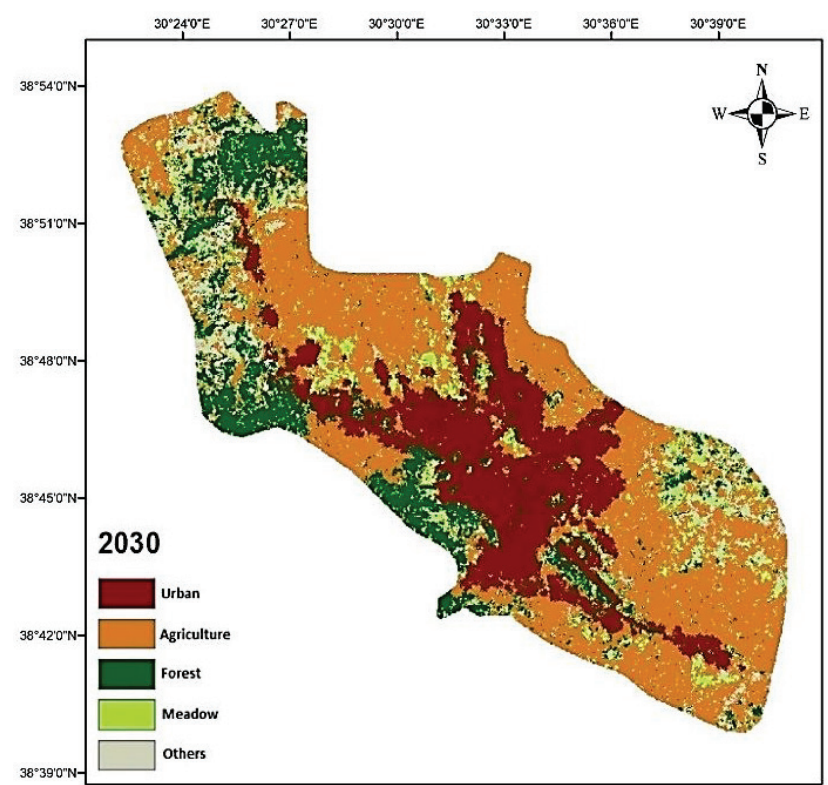

Figure 14 Current Growth Prediction Results

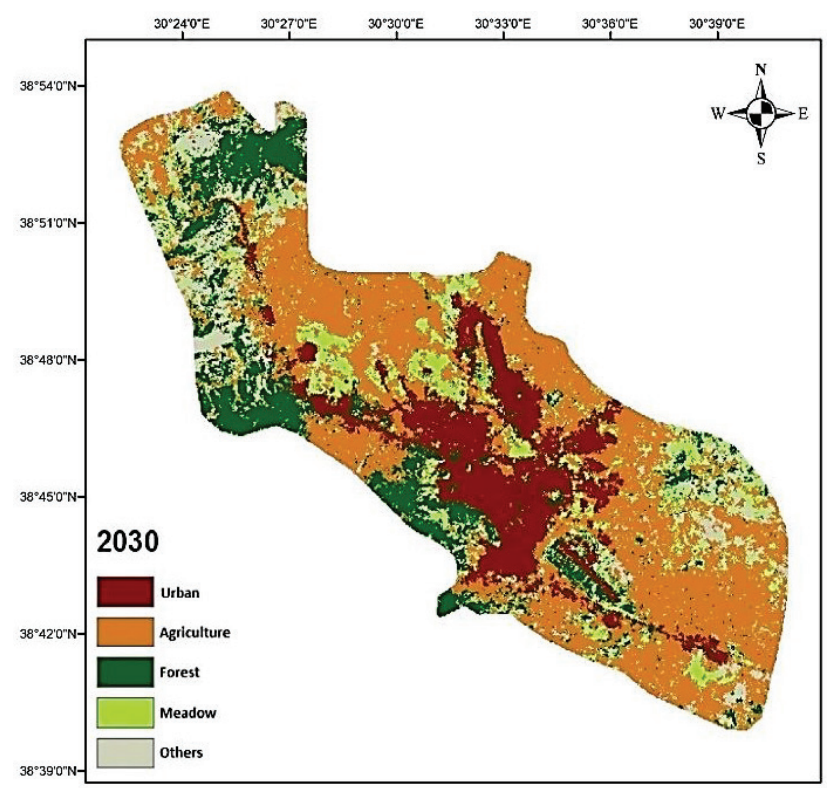

Figure 15 Controlled Growth Prediction Results

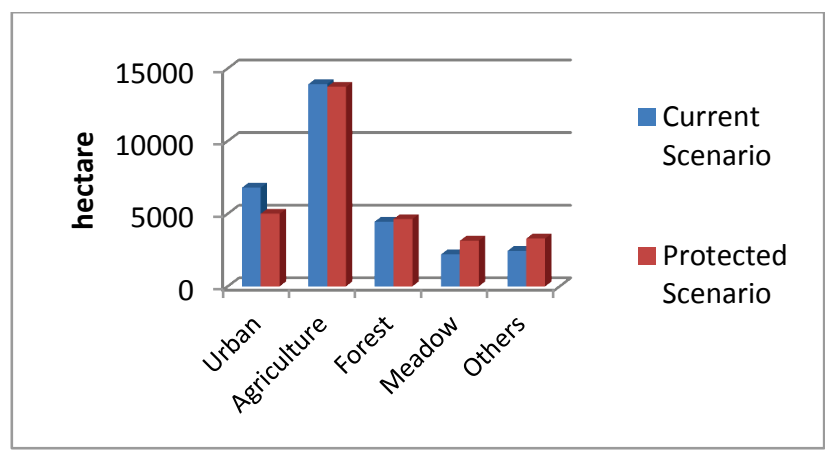

Figure 16 Current and controlled scenario areal graphic

A process that begins with the destruction of meadows passes on to agricultural areas in the following years. In addition, agricultural lands have increased since 1987 and increases in future scenarios are also outstanding. The reason is because the unsuitable areas for agriculture whose majority consists of marsh has been dried and become suitable for agriculture naturally or artificially in addition to the transition of some areas used as meadows to agricultural areas. Additional work needs to be done to come to clearer conclusions about land cover and land use. In Fig. 17, the difference in urban growth between two scenarios is shown graphically.

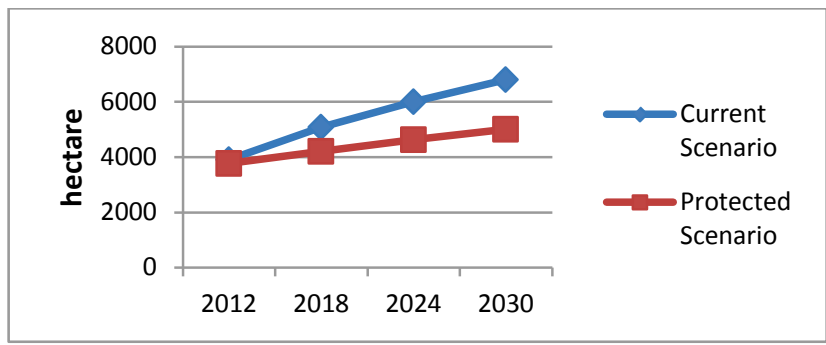

Figure 17 Urban area change graphic of current and controlled scenario

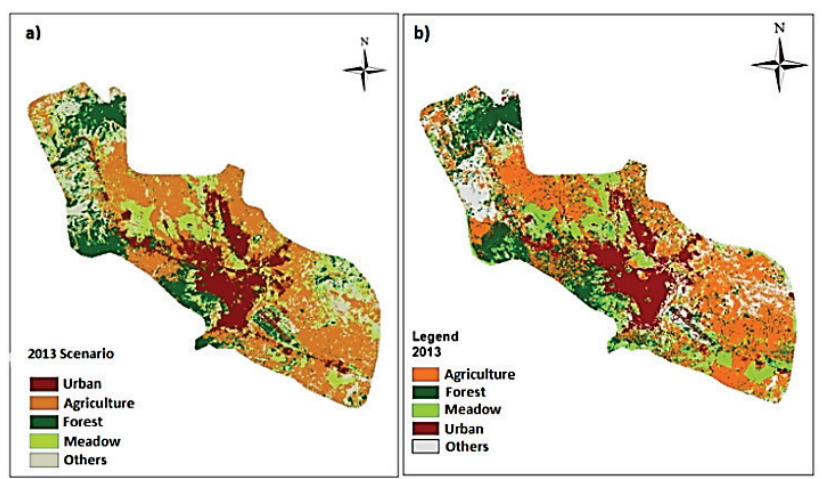

Figure 18 a) 2013 scenario, b) 2013Afyonkarahisar land use

The scenarios from 2012 to 2030 were created by SLEUTH model. In order to compare, land use was detected using 2013 Landsat 8 image of the same study area by classifying controlled (Fig. 18b). Actual land use in 2013 was compared with the 2013 scenario and high consistency was found. While the city area was 4015 ha in current land use in 2013, it was found to be 4125 ha in the 2013 scenario. Although there could not be mentioned an overall accuracy of the 2030 simulation, the comparison for the year 2013 was identified with $97 \%$ accuracy. The comparison has been done in the near future; however, it is expected this high accuracy will affect the overall accuracy and the scenario in 2030 will have high accuracy, too. For control purposes, meadow fields were compared and the model created by the current scenario in 2013 showed 4432 ha meadow areas whereas meadow land obtained from current 2013 image was 4048 ha. $90 \%$ of accuracy was identified in the meadow 2013 areas and $97 \%$ accuracy for 2013 urban areas.

\section{Conclusion}

Sleuth Model is one of the best visual modelling whose results can guide managers and city planners' ideas for the future of the city and the precautions that should be taken. The predictions of this model are useful images in the sense of public awareness in cities and showing what kind of problems uncontrolled urban growth produces and what rationalizing measures should be 
taken. In particular, state and territory agencies in the United States Sleuth have come to realize the potential of SLEUTH model and use it as a tool for modelling the fragility of the natural areas. That is, the ever-increasing growth of world cities causing social, economic and environmental problems has developed the interest in managing the urban future. Therefore, it is highly necessary to understand urban dynamics and to assess the impacts of urban growth on the environment and that needs modelling. Due to its ability to simulate complex and dynamic movements of urban systems, cellular automata (CA) models take part as an appropriate approach in the modelling of regions and cities. There are important functions of Sleuth model such as the development of interactive scenario, measure and visualization of results. Sleuth model can be used as a useful tool to assess the implications of alternative scenarios and to manage the urban growth.

The evaluation results of this urban study provide insight into the ability to guide the future of the city. In the first phase of the study, it was found that Afyonkarahisar city centre grew approximately by 3000 ha from 1987 until 2011. Subsequently, urban growth trend, parameters trained and constructed with the Sleuth model and 2030 scenarios were created from the past to the present with the help of satellite data. As a result of the study, with the current growth scenario, urban development from 2011 to 2030 will increase by 3115 hectares, and it is seen that 2300 hectares of pasture areas will be destroyed with this increase. It is found that 2000 ha of natural areas can be protected from urbanization and the wrong land use of the city's natural resources having social and economic importance can be avoided with the controlled growth scenario.

Although the Sleuth model is appropriate for simulation of protected scenario effects, it is insufficient in the simulation of potential effects of optimum scenarios. For instance, it is not quite likely for the SLEUTH model to simulate compact settlement of the city center.

\section{Acknowledgements}

This study was supported by Afyon Kocatepe University under project number 12FENBIL32.

\section{References}

[1] Stalker P. Handbook of World. Oxford University Press. New York. 2000.

[2] Batty, M. Cities and Complexity: Understanding Cities Through Cellular Automata, Agent-Based Models and Fractals, 2005.

[3] Oğuz, H. Kahramanmaraș ve Gaziantep Kent Büyümesinin ve Arazi Kullanımı/Arazi Örtüsü Değişiminin 2040 Yılına Kadarki Simülasyonu. Tübitak-Çaydag, Project No: 109Y164

[4] Meaille, R.; Ward, L. Using geographical information systems and satellite imagery within a numerical simulation of regional urban growth. // International Journal of Geographical Information Systems. 4, (1990), pp. 445-456. DOI: 10.1080/02693799008941558

[5] Grossman, W.; Eberhardt, S. Geographical information systems and dynamic modeling potentials of a new approach. In M. Fischer and P. Nijkamp (eds.), Geographic information systems, spatial modeling and policy evaluation. New York: Springer-Verlag, 1993, pp. 167-180. DOI: 10.1007/978-3-642-77500-0_11

[6] Batty, M.; Longley, P. Fractal cities - A geometry of form and function. New York: Academic Press. 1994.

[7] Turkish Statistical Institute (TSI) Provincial Population Information, 2014

[8] Gigalopolis Project,Urban and Land Cover Modeling http://www.ncgia.ucsb.edu/projects/gig/ (Date accessed: $10 / 12 / 2013)$

[9] Campbell, J. B. Introduction to Remote Sensing, Second Edition, Virginia Polytechnic Institute and State University, The Guildford Press, NY, 1996

[10] Foody, G. M. Status of Land Cover Classification Accuracy Assessment. // Remote Sensing and Environment. 80, (2002), pp. 185-201. DOI: 10.1016/S0034-4257(01)00295-4

[11] İnan, M. Orman Varlığının Saptanmasında Uzaktan Algılama Verileri, İÜ. Fen Bilimleri Enstitüsü Doktora Tezi, İstanbul.Franklin, G. F.; Powel, J. D.; Workman, M. L. Digital Control of Dynamic System. Addison-Wesley Publishing Company, Massachusetts, 1990/2004.

\section{Authors' addresses}

Mustafa Mutlu Uysal, Engineer

The Ministry of Forest and Water Affairs,

3th Reginal Office, Balıkesir, Turkey

E-mail: mustafamutluuysal@yahoo.com.tr

Murat Uysal, Assistant Prof

Afyon Kocatepe University, Faculty of Engineering, Geomatics Engineering,

ANS Campus TR-03200, Afyonkarahisar, Turkey.

E-mail:muysa1007@gmail.com 